\title{
UJI EFEK ANALGESIK EKSTRAK DAUN PICISAN (Polypodium nummulariifolium Mett.) PADA MENCIT SWISS (Mus musculus)
}

\author{
${ }^{1}$ Angelia Tudang \\ ${ }^{2}$ Jane Wuisan \\ ${ }^{2}$ Johanis A.Najoan W \\ ${ }^{1}$ Kandidat Fakultas Kedokteran Unsrat \\ ${ }^{2}$ Bagian Farmakologi dan Terapi Fakultas Kedokteran Unsrat \\ Email: angelia@gmail.com
}

\begin{abstract}
Picisan leaf is one of the plants that can be used as medicine. It can heal pain and also act as analgesic. The purpose of this research is to determine Analgesic effect on mice by using picisan leaf extract. The research has been done experimentally method. The substances dissolved in maseration way with $95 \%$ alcohol solvent. There are 3 groups of mice that used in this experiment. Each group has 3 mice of gender male and female. First group is a group with control positive using tramadol; second group is control negative using distilled water ; and the third group is treated by the extract of Picisan leaf. The testing method of analgesic effect is thermal stimulation. Data collection is defined by measuring movements variable of mice, such as legs licking or jumping. Result After stimulated by picisan extract, the average respond of mice show a deflation in minute $30^{\text {th }}$. The average respond keep declining until minute $120^{\text {th }}$. This phenomenon is compared to mice respond before stimulated by picisan extract. In conlusion, Picisan leaf extract shows analgesic effect on mice.
\end{abstract}

\begin{abstract}
Abstrak: Salah satu tanaman yang telah lama digunakan sebagai pengobatan yaitu daun picisan (Polypodium nummulariifolium Mett.). Daun picisan diyakini mempunyai banyak khasiat salah satunya sebagai obat untuk menghilangkan nyeri (analgesik). Tujuan penelitian ini yaitu untuk mengetahui apakah ekstrak daun picisan mempunyai efek analgesik pada mencit. Penelitian ini merupakan penelitian yang bersifat eksperimental. Ekstraksi bahan dilakukan dengan cara maserasi dengan menggunakan pelarut alkohol 95\%. Hewan uji yang digunakan adalah mencit swiss (Muss musculus) berjenis kelamin jantan dan betina sebanyak 9 ekor, kemudian dibagi dalam 3 kelompok yang masing-masing terdiri dari 3 ekor mencit yaitu: kelompok kontrol positif dengan menggunakan tramadol, kelompok kontrol negatif menggunakan aquades, dan kelompok perlakuan yang diberi ekstrak daun picisan. Pengujian efek analgesik menggunakan metode rangsang panas. Data yang diperoleh dinilai dari respon mencit berupa gerakan mencit yang menjilat kaki dan atau melompat. Hasil Penelitian memperlihatkan bahwa terjadi penurunan jumlah rata-rata respon mencit setelah pemberian ekstrak daun picisan yaitu pada menit ke 30 dan terus mengalami penururan respon hingga menit ke 120 dibandingkan dengan respon rata-rata mencit sebelum diberikan perlakuan. Berdasarkan hasil penelitian maka dapat disimpulkan bahwa ekstrak daun picisan memiliki efek analgesik pada mencit.
\end{abstract}

Pada umumnya penyakit pada tubuh menimbulkan rasa nyeri. Definisi nyeri menurut The International Asosiation for the Study of Pain ialah suatu pengalaman sensorik dan emosional yang tidak menyenangkan yang disertai oleh kerusakan jaringan secara potensial dan aktual. Rasa nyeri merupakan mekanisme perlindungan dan mekanisme pertahanan bagi tubuh. Selain itu nyeri juga berfungsi sebagai 
defensif yaitu memungkinkan untuk immobilisasi organ tubuh yang mengalami inflamasi atau patah sehingga sensible yang dirasakan akan mereda dan bisa mempercepat penyembuhan, nyeri juga berfungsi sebagai penuntun diagnostik, karena dengan adanya nyeri pada daerah tertentu, proses yang terjadi pada pasien dapat diketahui. Nyeri dirasakan oleh penderita yang sadar pada tingkat kritis korteks serebri yang paling tinggi. Rasa nyeri timbul bila ada kerusakan jaringan aktual atau potensial, dan hal ini akan menyebabkan individu bereaksi dengan cara memindahkan stimulus nyeri untuk menghilangkan rangsang nyeri tersebut.

Umumnya masyarakat mengkonsumsi obat-obatan analgesik baik itu golongan opioid maupun non opiod. Akan tetapi pemanfaatan obat-obat tersebut sering kali menimbulkan efek samping apalagi penggunaan obat dalam jangka waktu yang lama. Banyaknya efek samping yang ditimbulkan dari obat-obat analgesik tersebut maka perlu dilakukan pengkajian terhadap tanaman obat tradisional. Saat ini pengetahuan dan pemahaman masyarakat mengenai tumbuhan berkhasiat obat semakin berkembang. Masyarakat mulai memahami bahwa penggunaan tumbuhan berkhasiat obat sebenarnya bisa sejajar dan saling mengisi dengan pengobatan modern. Tidak jarang, penggunaan tumbuhan berkhasiat obat dengan berbagai alasan herbal dijadikan sebagai pilihan utama untuk pengobatan. Dengan semakin meningkatnya kesadaran tersebut, riset-riset ilmiah pun kini semakin banyak diarahkan pada bahan-bahan alami untuk mengetahui keseluruhan efek khasiat yang terkandung dalam tanaman obat tersebut. Di Indonesia, dikenal lebih dari 20.000 jenis tumbuhan obat, namun baru 1.000 jenis tanaman telah terdata dan baru sekitar 300 jenis yang sudah dimanfaatkan untuk pengobatan tradisional. Salah satu tanaman yang telah lama digunakan sebagai pengobatan yaitu daun picisan. Daun picisan diyakini memiliki banyak khasiat diantaranya yaitu sebagai antiradang, antinyeri (analgesik), membersihkan darah, menghentikan perdarahan (hemostasis), memperkuat fungsi paru-paru dan sebagai obat batuk (antitusif). Pokok permasalahan dari penelitian ini yaitu apakah ekstrak daun picisan (Polypodium nummulariifolium Mett.) mempunyai efek analgesik?

Dengan adanya penelitian ini maka diharapkan dapat diperoleh data ilmiah mengenai efek analgesik ekstrak daun picisan

\section{METODE PENELITIAN}

\section{Bentuk Penelitian}

Penelitian ini menggunakan metode eksperimental.

\section{Waktu dan Tempat Penelitian}

Penelitian dilakukan dari bulan Oktober 2012 sampai Januari 2013. Penelitian ini dilakukan di Laboratorium Farmakologi dan Terapi Fakultas Kedokteran UNSRAT Manado.

\section{Subjek Penelitian}

Penelitian ini menggunakan Mencit Swiss (Mus musculus) sebanyak 9 ekor sebagai hewan uji.

Hewan uji dibagi dalam tiga kelompok masing-masing terdiri atas 3 ekor yaitu :

- Kelompok 1 sebagai kontrol positif, yang diberi Tramadol.

- Kelompok 2 sebagai kontrol negatif, yang diberi Aquades\

- Kelompok 3 sebagai kelompok perlakuan yang diberi ekstrak daun picisan

\section{Prosedur Penelitian}

1. Pembuatan ekstrak daun picisan (Polypodium nummulariifolium Mett.) dibuat dengan metode maserasi dan menggunakan pelarut alkohol 95\%.

2. Persiapan hewan uji. Hewan uji yang digunakan adalah mencit swiss (Mus musculus). Berat badan mencit yang digunakan berkisar 20-30 gram. Kemudian dipuasakan selama $\leq 11$ jam. 
3. Penyiapan Zat Uji Dan Larutan Pembanding

a. Ekstrak Daun Picisan

Ekstrak daun picisan dibuat dalam larutan 10\%. Diaduk sampai homogen. Diambil sebanyak 0,5 ml dengan semprit $1 \mathrm{ml}$ untuk diberikan pada tiap hewan uji.

b. Kontrol Positif

Untuk kontrol posotif, larutan pembanding yang akan digunakan yaitu tramadol $50 \mathrm{mg}$. Dosis tramadol yang digunakan untuk manusia adalah $100 \mathrm{mg} / 50 \mathrm{kgBB}$ untuk sekali pemberian. Tramadol kemudian dijadikan larutan 100\% dengan melarutkan $50 \mathrm{mg}$ bubuk tramadol dalam $50 \mathrm{ml}$ aquades. Konversi perhitungan dosis untuk sekali minum pada mencit dengan asumsi bobot mencit $20 \mathrm{~g}$ pada manusia normal $70 \mathrm{~kg}$ adalah 0,0026 (Laurence \& Bacharach: 1964).

perhitungan dosis untuk berat badan $50 \mathrm{~kg}$ yaitu :

Dosis mencit $=50 \mathrm{~kg} / 70 \mathrm{~kg} \times 100 \mathrm{mg}$ $\mathrm{x} 0,0026 \mathrm{mg}=0,18 \mathrm{mg} / 20 \mathrm{~g}$ mencit

$0,18 \mathrm{mg}$ dosis tramadol untuk mencit kemudian dilarutkan dengan aquades hingga diperoleh 0,5 ml untuk diberikan pada tiap hewan uji.

c. Kontrol Negatif

Untuk kontrol negatif, dipergunakan aquades. Diambil 0,5 ml untuk diberikan pada tiap hewan uji.

4. Pemberian zat uji yang dilakukan per oral dengan menggunakan semprit 1 ml dan NGT (Nasogastrik Tube) pediatrik no. 3,5

5. Pengujian efek analgesik dengan menggunakan metode rangsang panas dengan suhu yaitů $55 \mathrm{C}$ sebagai stimulus nyeri. Data dinilai dari respon mencit berupa gerakan mencit yang menjilat kaki dan atau melompat. Hasil pengamatan terhadap respon hewan uji dari masing-masing kelompok perlakuan dicatat dan kemudian dibandingkan

\section{HASIL PENELITIAN}

Data hasil penelitian berikut merupakan data yang diperoleh dari 3 kelompok hewan uji yakni kelompok kontrol positif, kontrol negatif dan kelompok perlakuan dimana setiap kelompok hewan uji masing-masing terdiri dari 3 ekor mencit sebagai hewan uji.

Tabel 1 memperlihatkan bahwa ratarata jumlah respon mencit sebelum pemberian yaitu 36,7 kali dibulatkan menjadi 37 kali. Pada menit ke-30 setelah pemberian mengalami penurunan jumlah respon rata-rata yaitu 27,3 kali dibulatkan menjadi 27 kali, kemudian pada menit ke-60 respon rata-rata yaitu 18,7 kali dibulatkan menjadi 19 kali, dan pada menit ke-90 respon rata-rata terus menurun yaitu 10,3 kali dibulatkan menjadi 10 kali, dan kemudian pada menit ke-120 jumlah ratarata respon mencit yaitu 15,3 kali dibulatkan menjadi 15 kali.

\section{Kelompok Kontrol Positif}

Tabel 1. Hasil Pengamatan Respon Mencit Kelompok Kontol Positif (Tramadol)

\begin{tabular}{|c|c|c|c|c|c|c|c|c|c|c|c|c|c|c|}
\hline \multicolumn{14}{|c|}{ Waktu } & \\
\hline \multicolumn{4}{|c|}{ Sebelum } & \multicolumn{11}{|c|}{ Setelah Perlakuan } \\
\hline \multirow{2}{*}{$\begin{array}{c}\text { Kelompok } \\
\text { L J }\end{array}$} & \multicolumn{3}{|c|}{ Perlakuan } & \multicolumn{2}{|c|}{$30^{\prime}$} & \multicolumn{2}{|c|}{60} & \multicolumn{2}{|l|}{90} & \multicolumn{5}{|c|}{120} \\
\hline & $\mathrm{T}$ & $\mathrm{L}$ & $\mathrm{J}$ & $\mathrm{T}$ & $\mathrm{L}$ & $\mathrm{J}$ & $\mathrm{T}$ & $\mathrm{L}$ & $\mathrm{J}$ & $\mathrm{T}$ & $\mathrm{L}$ & $\mathrm{J}$ & $\mathrm{T}$ & \\
\hline Mencit 10 & $\overline{43}$ & $\overline{43}$ & $\overline{0}$ & 39 & 39 & 2 & $\overline{23}$ & 25 & 1 & 19 & 20 & 10 & 13 & 23 \\
\hline Mencit 20 & 37 & 37 & 0 & 21 & 21 & 0 & 15 & 15 & 0 & 10 & 10 & 0 & 11 & 11 \\
\hline Mencit 30 & 30 & 30 & 2 & 20 & 22 & 2 & 14 & 16 & 1 & 0 & 1 & 3 & 9 & 12 \\
\hline Jumlah & 110 & & & 82 & & & & 6 & & & 31 & & & 46 \\
\hline Rata-rata & 36, & & & 27 & & & & 8,7 & & & 10, & & & 15,3 \\
\hline
\end{tabular}

Ket: $\quad$ L $=$ Lompat, $\mathrm{J}=$ Jilat, $\mathrm{T}=$ Total 


\section{Kelompok Perlakuan}

Tabel 2. Hasil Pengamatan Respon Mencit Kelompok Perlakuan

\begin{tabular}{|c|c|c|c|c|c|c|c|c|c|c|c|c|c|c|}
\hline \multicolumn{15}{|c|}{ Waktu } \\
\hline \multicolumn{4}{|c|}{ Sebelum } & \multicolumn{11}{|c|}{ Setelah Perlakuan } \\
\hline Kelompok & \multicolumn{3}{|c|}{ Perlakuan } & \multicolumn{2}{|c|}{30 ' } & \multicolumn{2}{|l|}{60} & \multicolumn{2}{|l|}{90} & \multicolumn{5}{|c|}{120} \\
\hline L J & $\overline{\mathrm{T}}$ & $\bar{L}$ & $\bar{J}$ & $\mathrm{~T}$ & $\mathrm{~L}$ & $\mathrm{~J}$ & $\mathrm{~T}$ & $\bar{L}$ & $\mathrm{~J}$ & $\bar{T}$ & $\mathrm{~L}$ & $\mathrm{~J}$ & $\overline{\mathrm{T}}$ & \\
\hline Mencit 10 & 48 & 48 & 0 & 30 & 30 & 0 & 14 & $\overline{14}$ & 0 & 17 & 17 & 0 & 18 & 18 \\
\hline Mencit 230 & 3 & 33 & 29 & 7 & 36 & 20 & 3 & 23 & 0 & 18 & 18 & 0 & 18 & 18 \\
\hline Mencit 33 & 28 & 31 & 1 & 25 & 26 & 0 & 10 & 10 & 0 & 8 & 8 & 0 & 8 & 8 \\
\hline Jumlah & 112 & & & 92 & & & & 7 & & & 43 & & & 44 \\
\hline Rata-rata & 37 & & & 30 & & & & 5,6 & & & 14,3 & & & 14,6 \\
\hline
\end{tabular}

Ket: $\quad \mathrm{L}=$ Lompat, $\mathrm{J}=$ Jilat, $\mathrm{T}=$ Total

\section{Kelompok Kontrol Negatif}

Tabel 3. Hasil Pengamatan Respon Mencit Kelompok Kontrol Negatif (Aquades)

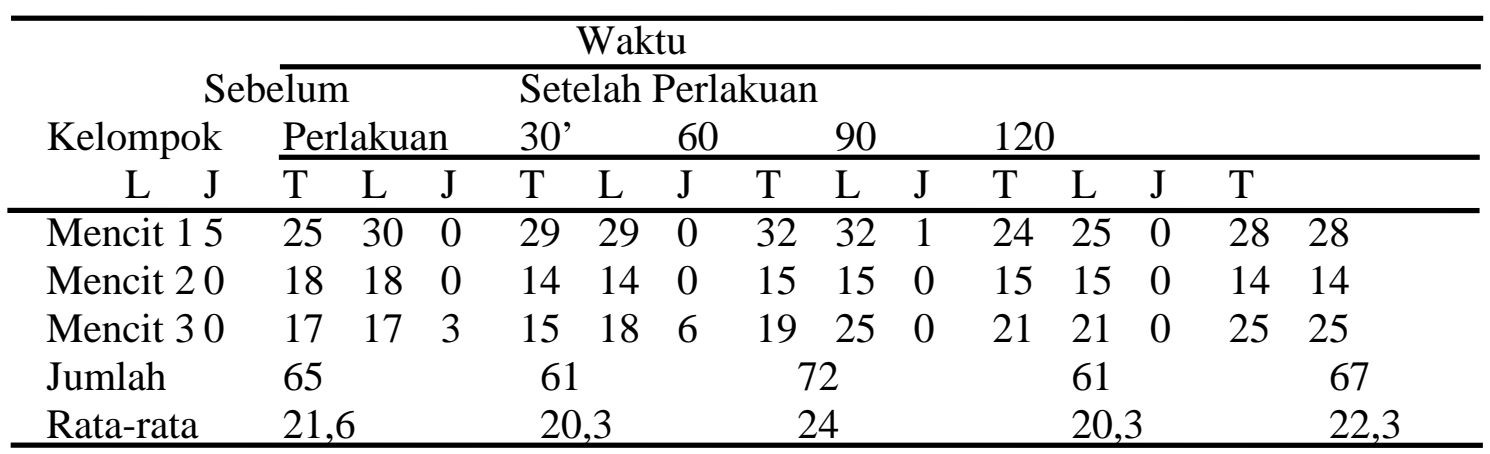

Ket: $\mathrm{L}=$ Lompat, $\mathrm{J}=$ Jilat, $\mathrm{T}=$ Total

Tabel 2 memperlihatkan bahwa jumlah respon rata-rata mencit sebelum pemberian ekstrak daun picisan yaitu 37,3 kali dibulatkan menjadi 37 kali. Pada menit ke-30 setelah pemberian mulai terlihat efek analgesik dengan penurunan jumlah respon rata-rata yaitu 30,6 kali dibulatkan menjadi 31 kali, kemudian pada menit ke-60 jumlah respon rata-rata terus menurun yaitu 15,6 kali dibulatkan menjadi 16 kali, dan terus menurun pada menit ke-90 dengan jumlah respon rata-rata yaitu 14,3 kali dibulatkan menjadi 14 kali, sampai pada menit ke-120 jumlah respon rata-rata mencit yaitu 14,6 kali dibulatkan menjadi 15 kali.

Tabel 3 memperlihatkan bahwa ratarata jumlah respon mencit sebelum pemberian aquades yaitu 21,6 kali dibulatkan menjadi 22 kali. Pada menit ke-
30 setelah pemberian respon rata-rata yaitu 20,3 kali dibulatkan menjadi 20 kali, kemudian pada menit ke-60 respon rata-rata mengalami kenaikan menjadi 24 kali, dan pada menit ke-90 respon rata-rata mengalami penurunan yaitu 20,3 kali dibulatkan menjadi 20 kali, dan kemudian pada menit ke-120 respon rata-rata yaitu 22,3 kali dibulatkan menjadi 22 kali.

Gambar 1 memperlihatkan grafik perbandingan rata-rata jumlah respon mencit kelompok kontrol positif dengan menggunakan tramadol dan kelompok perlakuan yang diberi ekstrak daun picisan mengalami penurunan setelah dilakukan perlakuan, sedangkan rata-rata respon mencit kelompok kontrol negatif dengan menggunakan aquades terlihat cenderung stabil. 


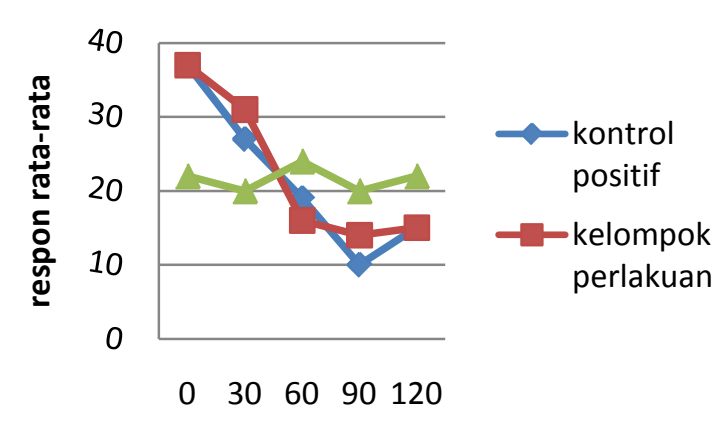

Waktu (Menit)

Gambar 1. Grafik Perbandingan Rata-Rata Jumlah Respon Mencit.

\section{PEMBAHASAN}

Pada penelitian ini telah dilakukan pengujian pada hewan percobaan yang bertujuan untuk mengetahui apakah ekstrak daun picisan mempunyai efek analgesik, dengan menggunakan pembanding yaitu tramadol sebagai kontrol positif dan aquades sebagai kontrol negatif. Sensasi nyeri ditimbulkan secara eksperimental dengan menggunakan metode hot plate. Data yang diperoleh dinilai dari respon mencit berupa gerakan mencit yang menjilat kaki dan atau melompat. Hewan percobaan yang digunakan adalah mencit Swiss (Mus musculus).

Pada penelitian ini didapatkan rata-rata jumlah respon mencit yang terdiri dari 3 ekor mencit pada kelompok perlakuan yang diberikan ekstrak daun picisan terlihat adanya penurunan jumlah rata-rata respon nyeri dari mencit setelah perlakuan dibandingkan sebelum perlakuan. Efek analgesik ekstrak daun picisan mulai terlihat setelah perlakuan yaitu pada menit ke-30 dan terus memperlihatkan efeknya dengan adanya penurunan jumlah rata-rata respon nyeri yang terus-menerus hingga menit ke120. Puncak efek analgesik ekstrak daun picisan yaitu pada menit ke-90. Penurunan jumlah rata-rata ini menunjukkan bahwa ekstrak daun picisan mempunyai efek analgesik.

Pada kelompok kontrol positif dengan menggunakan tramadol, efek analgesik mulai terlihat pada menit ke-30 setelah pemberian. Kemudian terus mengalami penurunan jumlah rata-rata respon nyeri pada menit ke-60 hingga mencapai puncak pada menit ke-90. Pada manusia efek analgesik tramadol timbul pada 1 jam setelah pemberian oral dan mencapai puncak pada jam ke-2 sampai ke-3. Hal ini dapat terjadi karena setiap individu mempunyai gambaran farmakokinetik obat yang berbeda-beda. Dosis yang sama pada suatu obat bila diberikan pada sekelompok orang dapat menunjukkan kadar dalam darah yang berbeda-beda dengan intensitas respon yang berlainan pula.

Data yang diperoleh dari hasil penelitian ini membuktikan bahwa efek analgesik ekstrak daun picisan tidak jauh berbeda dari tramadol. Hal ini terlihat dari penurunan jumlah respon rata-rata nyeri dari ekstrak daun picisan yang masih cenderung kuat hingga menit ke-120, dibandingkan dengan kelompok kontrol positif dengan menggunakan tramadol yang mencapai efek puncak pada menit ke-90 dan mengalami penurunan pada menit ke-120 meskipun efek analgesiknya masih terlihat.

Dalam penelitian ini respon yang terlihat dari setiap mencit yang digunakan sebagai hewan coba berbeda-beda, hal ini dapat terjadi karena banyak faktor. Salah satu faktor yang diduga dapat mempengaruhi hal tersebut yaitu laju dan metabolisme obat yang berbeda dari setiap mencit, adapun faktor-faktor yang mempengaruhi laju dan metabolisme obat yaitu; yang pertama faktor internal (fisiologis dan patologis) yaitu spesies, genetik (galur), seks, umur, hormon, kehamilan, penyakit dan lain-lain, kemudian yang kedua faktor eksternal (eksogen) yaitu makanan (diet), lingkungan dan lain-lain.

Hasil pengamatan pada kelompok kontrol negatif dengan menggunakan aquades memperlihatkan jumlah rata-rata respon nyeri pada mencit mengalami peningkatan dan penurunan yang tidak signifikan baik itu sebelum pemberian aquades maupun setelah pemberian aquades. 
Hal ini menunjukkan bahwa aquades tidak memiliki efek analgesik.

\section{SIMPULAN}

Dari hasil penelitian yang telah dilakukan mengenai uji efek analgesik ekstrak daun picisan pada mencit, maka dapat disimpulkan bahwa daun picisan memiliki efek analgesik pada mencit Swiss (Mus musculus).

\section{UCAPAN TERIMA KASIH}

Ucapan terima kasih disampaikan pada Prof. dr. Jimmy Posangi, MSc, PhD, SpFK dan dr. Christy Mambo, MSc dan pada semua pihak yang baik secara langsung maupun tidak langsung telah menumbuhkan ide atau gagasan dalam pemikiran penulis sehingga dapat menyelesaikan artikel ini.

\section{DAFTAR PUSTAKA}

1. Guyton and Hall: Buku Ajar Fisiologi Kedokteran; Edisi 11. Jakarta: EGC; 2007. h. 625-26.

2. Latief SA, Suryadi KA, Dachlan MR. Petunjuk Praktis Anastesiologi. Edisi Kedua. Jakarta: Bagian Anestesiologi dan
Terapi Intensif Fakultas Kedokteran UI; 2001. h. 74-5.

3. Guyton. Fisiologi Manusia dan Mekanisme Penyakit. Edisi III, Revisi. Jakarta: EGC; 1990. h. 443-44.

4. Mangku G, Senapthi TGA. Buku Ajar Ilmu Anestesia dan Reanimasi. Dalam; Wiriana IM, Sinarja IK, Budiarta IG, editor. Jakarta: PT Indeks; 2009. h. 217-19.

5. Boulton TB, Blogg CE, Hewer CL. Anestesiologi (Anasthetics For Medical Students). Dalam: Wulandari WD, editor. Edisi 10. Jakarta: EGC; 1994. h. 12.

6. Kusuma FR, Zaki MB. Tumbuhan Liar Berkhasiat Obat. Jakarta: Agromedia Pustaka; 2005. h. 6.

7. Aprianti M. 10 Tanaman Obat Paling Berkhasiat \& Paling Dicari. Yogyakarta: Pustaka Baru Press; 2012. h. v.

8. Hariana A. Tumbuhan Obat \& Khasiatnya. Seri 2. Jakarta: Penebar Swadana; 2008. h. 5.

9. Dalimarta S. Atlas Tumbuhan Obat Indonesia. Jilid 2. Jakarta: Trubus Agriwidya; 2000. h. 178-81.

10. Dewoto HR. Farmakologi dan Terapi: Analgesik Opioid \& Antagonis. Edisi 5. Jakarta; 2007. h. 210-12.

11. Rahardjo R. Kumpulan Kuliah Farmakologi. Edisi Kedua. Jakarta: EGC; 2008. h. 16.

12. Gibson GG, Skett P. Pengantar Metabolisme Obat. Jakarta: Universitas Indonesia Press; 1991. h. 120. 